\title{
Where have all the prophets gone? Perspectives on political preaching ${ }^{1}$
}

\author{
Cilliers, Johan \\ Stellenbosch University \\ jcilliers@sun.ac.za
}

\begin{abstract}
This article takes a brief look at the notions of voice, event, and experience within the communal paradigm of South African societies. This is followed by a description of different ways in which political and eschatological preaching has been understood within recent times, starting with the reverted eschatology of apartheid sermons, linked to the experience of fear; then the hopeful eschatology of Desmond Tutu's sermons, evoking experiences of anticipation; and concluding with what could be called the present day vacuum in this regard: preaching that strives to maintain by means of introverted eschatology, contributing to experiences of uncertainty.
\end{abstract}

Keywords

Political preaching; Prophetic voice; Dabar; Udaba

\section{Preaching between Dabar and Udaba}

The father of psychoanalysis, Sigmund Freud, once told the story of a little girl who was afraid of the dark. It was bedtime and she was alone in her room, with the nanny sitting in the room next door. The girl cried out: "Auntie, talk to me, I'm frightened", whereupon the nanny answered: "But what good will that do? You can't see me." The child replied: "If someone speaks, it gets brighter." 2

1 Abbreviated version of paper delivered at the Internationales Bugenhagen-Symposium. Atelier Sprache Braunschweig/ Theologische Fakultät Leipzig, on theme "Erlebnis Predigt". 16-18 September 2013.

2 Sigmund Freud, A General Introduction to Psychoanalysis (New York: Boni and Liveright, 1920), 352. 
Words create worlds; voices form spaces of comfort and grace, but also chaos and darkness. Words signify an oral event that evokes experiences - or at least has the potential to do so - of comfort or distress, of light or darkness. In this article, I will be looking at the oral event that we call preaching, seen as an event that evokes experience. The topic of my article refers specifically to the event of political and eschatological preaching. In the African context, with its communal understanding of life, an event can never be without an experience. ${ }^{3}$ In Africa words are for instance not primarily meant to be put on paper, but to live in the air as voice, in the spaces between people. It in fact creates these spaces, and is intended to bind community together in what could be called a communal experience.

The sound of the voice has always played an important role in African culture. ${ }^{4}$ As a matter of fact, in the South African language isiXhosa the same word is used for "word" and "voice" (Ilizwi). It is understood not as an abstract notion, but as an oral event that indeed intends experience - that in turn aims at behavioural change. When a mother in Africa for instance sings a lullaby to her infant (Tula Tu Tula baba, Tula sana Tul'umam 'uzobuya ekuseni) the words are not the dominant factor in comforting the child (although the words are not unimportant), the sound of her voice is. ${ }^{5}$

3 Africans, indeed, have a more systemic understanding of life. Life is a dynamic space for holistic relationships, an integral whole of cosmic and social events. Africans adopt a non-analytical approach to our existence on this planet, epitomized in the words of AA Berinyuu: "In Africa, there is no division and/or differentiation between the animate and inanimate, between the spirit and matter, between living and non-living, dead and living, physical and metaphysical, secular and sacred, the body and the spirit, etc. Most Africans generally believe that everything (human beings included) is in constant relationship with one another and with the invisible world, and that people are in a state of complete dependence upon those invisible powers and beings. Hence, Africans are convinced that in the activities of life, harmony, balance or tranquillity must constantly be sought and maintained. Society is not segmented into, for example, medicine, sociology, law, politics and religion. Life is a liturgy of celebration for the victories and/or sacrifices of others." Berinyuu A.A., Pastoral Care to the Sick in Africa (Frankfurt am Main: Peter Lang, 1988), 5. This differs from certain Western approaches to life. Whilst analyses, solutions and consumerism are typical of the latter, myth and symbol, ritual and rhythm determine everyday life in the African context.

4 Actually one cannot speak of African culture in the singular. Africa is a vast continent, incorporating a wide variety of cultures and ethnic groups. Northern Africa differs totally from Southern Africa. The term "Africa" does not denote one homogenous group.

5 It is interesting to note that music was called "sound-speech" (Klangrede) as far back as 1739, for instance by Johann Mattheson, Der vollkommene Capellmeister (Hamburg: Verlag von Warned, 1739), 17, 25. 
The words form the vehicle that carries the sounds of soothing; that facilitates the tones of nurturing. The words indicate an event that creates experience that results in behavioural change (the baby is comforted, and no longer cries).

Perhaps this understanding of word is not that far removed from the oral culture of the Old Testament, with its understanding of dabar. ${ }^{6}$ Dabar is not only word, but also simultaneously deed. ${ }^{7}$ Dabar not only intends understanding, but also transformation; it is both hermeneutical and agogisch in nature. ${ }^{8}$ The hermeneutical dimension of dabar implies discernment, wisdom, and the agogische dimension (from the Greek word $\dot{\alpha} \gamma \omega \gamma \dot{\eta})$ indicates guidance towards change. ${ }^{9}$ This process of understanding and transformation entails an event that is experienced - the eventful experience of having an encounter not with an idea or thing, but with Someone. With respect to the Apostle John: in the beginning was the Word that brings understanding of and transformation by this Someone; in the beginning was the Voice of this Someone that is simultaneously the Deed of this Someone. ${ }^{10}$

6 For a good overview, cf. WH Schmidt's discussion in Theological Dictionary of the Old Testament. Ed J Botterweck and H Ringgren, Volume III (Grand Rapids, Michigan: Eerdmans, 1997), 111-125. Schmidt links this word to the prophets of the Old Testament, and points out that dabar must always be understood as a historical and therefore contextual event.

7 G Gerleman rightly points out that dabar, although always being a historical and therefore contextual event also indicates a divine event, and "stands not only for 'word,' i.e., for the linguistic carrier of meaning, but also for the content itself." G Gerleman, Theological Lexicon of the Old Testament, Volume 1, Ed. E Jenni and Claus Westermann, translated by ME Biddle (Minneapolis: Hendrickson Publishers, 1997), 329.

8 The latter is to be distinguished from pedagogics. With both these dimensions (hermeneutics and agogics) the focus lies on the Subject who grants both understanding and change, and it is not simply the understanding of something, but Someone; not just change done by humans, but by God. Cf J Firet, Het Agogisch Moment in het Pastoraal Optreden (Kampen: Kok), 1982), 124-127.

9 Firet, Het Agogisch Moment, 132.

10 This obviously also echoes the classic translation of the prologue of the Gospel of John offered by Goethe in Faust. First he considers the translation: In the beginning was Sense; then: In the beginning was Power; and ultimately: In the beginning was the Deed. Johann Wolfgang von Goethe, Faust, Part I (Harvard: The Harvard Classics, 1909-14), 890-900. 
If we interpret this word-deed homiletically, it would mean that preaching is all about this event of God's voice, an event that is also deed. God's voice is simultaneously God's deed of revelation, God's presence, and God's face being turned towards us. The anthropomorphous expression the face (panim) expresses the modus of God's revelation strikingly: in this God's entire personality becomes clear and God's inner being is represented. This points to God's merciful presence (or the seemingly opposite: that God's countenance is hidden from us or turned away from us, implying that God wants to remain concealed - another mode of God's grace). ${ }^{11}$

With this expression - panim Jahwe - Israel wanted to confirm that the relation between God and humanity is real, but that God is never bound or restricted by God's revelation to us. ${ }^{12}$ To enter the space before the countenance of God does not in the first place indicate accessing a physical space, but the potential and mystery of encounters, with all of the experiences associated with that. These encounters can take place in any place, but God's presence (or concealment) cannot be explained purely in terms of physical categories.

This word-deed shapes experience and calls for transformation. Preaching is the event of God's voice, but perhaps the latter can also be changed around: preaching is about the voicing of God's event. In this sense, the event of preaching can (and should be) be planned; but it can also not be planned; it can be created, and it cannot be created; it resembles what can be called "happenstance", i.e. something good that happens by chance (or, speaking theologically: through grace). Preaching is hard work, but it is also happenstance. This happenstance cannot be controlled or contained; it has its own life, breaking free from constraints. Preaching as an experience of happenstance points towards the unexpected, the surprising, the grace of God's face being revealed to us. ${ }^{13}$

11 Cf. Gen. 4:14; Psalms 104:29, etc.

12 Cf. TC Vriezen, Hoofdlijnen der Theologie van het Oude Testament (Wageningen: H Veenman en Zonen N.V., 1966), 228.

13 Cf. the discussion of "happenstance" by Daniël Louw, Network of the Human Soul. On Identity, Dignity, Maturity and Life Skills (Stellenbosch: Sun Press, 2012), 32, 42, 47. 
It is indeed, as the Old Testament concept of dabar entails: graceful events explained by means of words. ${ }^{14}$ When I speak about the sound of God's Voice, it is this sound-event that I have in mind, a sound-event that creates (spaces for meaning and life); but can also destroy (spaces that have become fixated and inhumane). It is Sound that is more than just volume, but rather form-giving; it is Sound that is more than just vocal, but also forgiving; it is Sound that brings light in darkness. In short: it is Sound that saves, Sound that signals a salvific event of encounter within the space created before God's face.

In the South African language isiXhosa the word for event is Udaba. Udaba indicates an unmistakeable event, a public happening, and a dynamic, often bodily performance. ${ }^{15}$ You cannot escape from it. Udaba means "serious business" - it is a matter of utmost importance, ${ }^{16}$ but is normally also understood as "good news". ${ }^{17}$ Originally it was used to express an event within a more rural context, for instance a ritual concerning the passages of life (birth, adulthood, marriage, death). When the village was called together by the traditional leaders, it was an Udaba - you could not excuse yourself from it. Currently the term has obtained more of a political character - when rallies are organised, protest marches take place, canvassing for votes are attended to, etc.

14 In the New Testament the notion of dabar is also interpreted as being more than a mere sound, or an abstract doctrine - it rather indicates actions (wherein God and people are involved), and it reaches its climax in the incarnation of Jesus. For a discussion of the ways in which the Old Testament concept of dabar is interpreted in the New Testament, cf. Frank R Ames, New International Dictionary of Old Testament Theology and Exegesis, Volume 1, Ed. Willem A Van Gemeren (Grand Rapids, Michigan: Zondervan Publishing House, 1997), 914-915.

15 A popular music group in South Africa goes by the name of Udaba - Burning Issue. They perform a fusion of Jazz, vernacular lyricism and African indigenous music. The central theme of the music is the use of African languages (isiXhosa) to inform especially illiterate rural youths about the dynamics of culture within the transforming African society. It draws inspiration from Xhosa oratory and translates it into musically meaningful ways - praise singing, lyrical essays and poetry.

16 In the isiXhosa translation of 2 Chronicles 9:1 the word Udaba is used to express the following: The Queen of Sheba goes to King Solomon "to test him with difficult questions".

17 Mavis Mpola makes an interesting link between Udaba and cultural and religious events. When the tribal leader calls the community together, everybody waits upon his words. These words signify an event that is both communal and experienced as good news, i.e. to the advantage of the community. Cf. Mavis Noluthando Mpola, An Analysis of Oral Literary Music Texts in IsiXhosa (Unpublished PhD: Rhodes University, 2007), 98, 100, 209, 234. 
However the term is used, the idea behind Udaba is always a communal event. An Udaba cannot take place in solitude or isolation. An Udaba furthermore rests on certain sources and traditions - it is not grasped from the air, but rather takes place within certain communal paradigms. But an Udaba also intends transformation, i.e. behavioural change. In the rural context, it means for instance that boys and girls that pass into the age of adulthood should now behave differently, because their identity has been transformed. This change takes place within the paradigms of tradition, and always in community with others. In the political context, the long history of for instance the struggle for freedom is constantly retold, in order to affect change, in order to serve the community of political kindred spirits. And, important to note, rituals with accompanying oral encouragements and directives, always form part of this Udaba.

To a certain extent, preaching as an event can be compared to the African notion of Udaba; perhaps Udaba can even be seen as an African metaphor for preaching. Preaching is an oral event, par excellence; it finds its voice from certain sources and traditions (in particular the Bible); it takes place within the community of the congregation; and it intends transformation, in a context of ritual (liturgy). Dare I say that, in the African context, preaching takes place in the movement (or space) between Dabar and Udaba? It is all about the sounds of a Voice, i.e. a Word that does not evaporate into abstraction, but rather enters a community, in order to affect change. It is about a Word that sounds (says), but in such a way that it does.

Said in more homiletical terms: preaching communicates more than mere information about God to others; it is the performance of God's voice, through historical distances, the mists of incomprehension and deafness of ears - in such a way that God's face is revealed. A sermon is more than the transfer of religious information, also more than words in a written manuscript. A sermon is not only an expression of a faith in search of understanding (fides quaerens intellectum); it is also an expression of a faith in search of sound (fides quaerens sonum) - the sound of God's voice that calls for the experience of an encounter before God's face. ${ }^{18}$ It represents a word event and a Word event, the sound of a voice, non-recurrent and unique. In fact,

18 Cf. Johan Cilliers, Das Klingen des Lebens: Liedübertragungen als Transfer religiöser Kulturpraxis: Das Kirchenlied zwischen Sprache, Musik und Religion. Veranstaltung 
sermons cannot be repeated, nor be re-preached, because God's voice is not static, not fixed in time and place, but historical, contingent, living and redeeming. Sermons are more than concepts or truths on paper, no matter how exegetical or dogmatically correct they may be. They rather represent a word that yearns to become a voice that articulates the Word that yearns to be a Voice heard.

\section{Enter the prophets...}

Seen from the perspective of Udaba, it is perhaps not an overstatement to say that preaching in South Africa has always been, in some way or other, political ${ }^{19}$ and eschatological ${ }^{20}$ in nature - taking our history and deepseated religiosity into account. In most of our ecclesiological traditions the notions of "political" and "eschatological" preaching would becombined and described as "prophetical preaching", unfortunately often in a theological unsophisticated manner. Most of the times prophetical preachers are

zu Ehren von Prof. Dr. Jürgen Henkys anlässlich seines 80. Geburtstages. Berliner Theologische Zeitschrift 20911; 28 (2): 279-299.

19 In my opinion theology and church (or in broader sense: religion) can contribute towards political processes. People - also religious people - need to develop stronger bonds with their political systems, resulting in the (public) re-shaping of democracy. According to Herfried Münkler we can discern three dimensions when we talk about the concept of politics: Polity in the sense of a formal structuring, which includes questions concerning the order of political systems, its norms, judicial arrangements, institutions, and organisations; Policy, which entails the formative and educational processes of politics, inclusive of specific aims and problem-solving mechanisms, understood within a specific framework of values, and Politics as the actual processes of communication of interests, of confrontation with other political systems, and the quest for building consensus within its own ranks. Cf. Herfried Münkler, Politik, in: TRE Bd. 27, Berlin/ New York 1997, 2. The specific contribution of religion might be linked particularly (but not exclusively) to the notion of Policy, in the sense that it can contribute towards the necessary dialogue about, and formation of ideas and values, and acting as a conduit in the search for problem-solving mechanisms.

20 Obviously the future by implication means "not now" - the future is the future - but this is often misunderstood as an experience of time exclusively related to a futurum, i.e. an attitude or mentality that somehow bypasses the present in its eagerness for the future. In the New Testament sense of the word, advent indicates a close connection between the saving presence of Christ who has already come and the future. The future is more about adventus (the coming of the present One), than it is about futurum. Jürgen Moltmann has written extensively on this topic. Cf. Jürgen Moltmann, Geloof in de toekomst (Uthrecht: Amboboeken, 1969), 177-178. Cf also Johan Cilliers, "Time out. Perspectives on liturgical temporality.” NGTT. (2009) 50 (1 and 2): 26-35. 
simply understood as those people who are addressing political issues from the pulpit, using, inter alia, eschatological (or apocalyptical) terms. ${ }^{21}$

We were indeed blessed with renowned "prophetical preachers" like Desmond Tutu, Allan Boesak, and Beyers Naude, who challenged political structures fearlessly during the era of apartheid, and in the process offered varied perspectives on eschatology. We also had, and still have, preachers who understood their "prophetic task" as maintaining the status quo and resisting disruptive influences - underlined by their own fitting "eschatology". And, obviously, we have always had, and definitely still have, many preachers - the silent majority - who simply avoid any political utterance or challenge (in effect thus legitimizing the status quo), again underlined by what they deem to be an appropriate "eschatology". ${ }^{22}$

People like Tutu, Boesak and Naude believed deeply in the transforming power of the Voice of God, as well as in the important role that preaching as an oral event could play in this regard. They used the Bible as their primary source for articulating an alternative society; and, understanding the importance of community and communal experience in the African context, they made an appeal on society (or: separated societies in South Africa during apartheid) to be transformed in the light of this rhetorically portrayed alternative society. This was in stark contrast to many preachers who wanted to maintain and preserve during the apartheid era, often out of fear for the risk of change.

21 Obviously, prophetic preaching can be described in various ways, also linked to cultural settings. According to Dawn Ottoni-Wilhelm, prophetic preaching reminds us of at least the following: the fact that God is compassionate, not deserting that which God has created; that God has made certain promises, expressing God's enduring faithfulness; and that there are alternatives manifestations of God's inbreaking new world, to be discerned even in our darkest moments. Dawn Ottoni-Wilhelm, "God's Word in the World: Prophetic Preaching and the Gospel of Jesus Christ", in Anabaptist Preaching: A Conversation Between Pulpit, Pew \& Bible, ed. David B. Greiser and Michael A. King (Telford, PA: Cascading Publishing House, 2003), 84-91. It would seem that the notion of imagination, as being part and parcel of the prophetic tradition, runs throughout almost all descriptions of prophetic preaching, Cf. the classic work by Walter Brueggemann, Prophetic Imagination (Philadelphia: Fortress Press, 1978), 33ff.

22 Allan Boesak refers to "the silence that some want the church to maintain on these issues (which) means that they are affirming the status quo." Allan Boesak, The Finger of God. Sermons on Faith and Responsibility. Translated from Afrikaans by Peter Randall (Johannesburg: Ravan Press, 1979), 11. 
The basic hermeneutical structure implemented by these preachers-ofmaintenance was crude, but effective. ${ }^{23}$ It consisted of three steps: First, the status quo was legitimized by means of biblical analogies (e.g. "As it was with Israel, so it is with South Africa"). This schematic analogy was used as a primary and primitive homiletic tool to stabilize the Afrikaner nation ("volk") in times of anxiety and turmoil, implying that as God was for Israel, so God is for the "volk". ${ }^{24}$ The use of this analogous scheme represented a search for security in a time of emergency. In the process God became the personification of an idea, a mechanism by which national viewpoints were projected on a metaphysical level. God became nationalized.

This movement backwards, into the security of historical analogies represented a way of escaping from time, from the continuation of time, and from God's self-revelation in time; it was a reaching back into history to avoid contemporary realities and the challenges of the future. It represented a particular form of anti-prophecy that does not dare to jump ahead, but rather arrests time and reproduces history.

Secondly, the listeners were admonished to guard zealously over their own "morality", to move inwards, into their "potential" as religious people. All the sermons included a type of "national programme" which consisted basically of moralizing appeals. The "volk" had to be strong and healthy. In this way God would ensure its future. The (Afrikaner) people were called upon to dig deep into themselves, to become introspective, to find the answers to the crises in the recesses of their inner potential.

In sermons like these, theological articulations become moralistic appeals; given situations (in which God acts) become conditional situations (in which people must act); for example: "If we as Afrikaners can act again like the people of Israel, God will bless us exactly as God blessed Israel"; "If we as Afrikaners have faith like Abraham, God will lead us to our destiny, just as God led Abraham", etc. ${ }^{25}$ Like I said, crude, but effective.

23 Cf. my detailed analyses of this stereotypical hermeneutical structure, in Johan Cilliers, God for Us? An Analysis and Assessment of Dutch Reformed Preaching during the Apartheid Years (Stellenbosch: Sun Press, 2006).

24 The Afrikaans word "volk" constitutes a key concept in these sermons. "Volk" could be translated as people or nation, but explicitly meant the white Afrikaner as an ethnic group.

25 Cf. Cilliers, God for Us?, 19. 
Thirdly, the "outsiders" were turned into enemies and in fact demonized. Now the movement was outwards, projecting guilt onto the "enemy". One of the ways in which the security (identity) of the people was stabilized in these sermons was by projecting guilt onto others. A dualism was formed between the "inner group" (the nation) and the "external group" (the enemies).

The primary function of this projection of guilt was self-justification; in the sense that a negative delimitation of the others confirmed the nation's own identity. To the extent that the others were stigmatized as enemies of God, the nation was stabilized as friends of God; the polemic against the others strengthened the apology for one's own nation. Here we truly see the homiletics of apartheid at work: "we", the Afrikaners, are here (a minority against the world, but righteous in our actions); and "they", the enemy are there (a majority and intrinsically evil). "We" must be kept apart and intact as a people at all costs.

We could say that sermons like these reverted and perverted eschatology; in effect turning it upside down. In a temporal sense, the clock was perpetually turned backwards, in search of historical anchors to stabilize the "volk" in the present; the novum of God's surprising and often disturbing future continuously breaking into the presence - God's face being turned towards us - was not entered to. The event of sermons like these (many of them being rhetorically very powerful) intended, or at least resulted in a certain paradoxical experience: it addresses the fear of the listeners, but also fuels it. And furthermore: on the grounds of this double-edged fear it calls for action, but not to change the status quo, rather to move deeper into the moralistic and exclusive world of the enclave. ${ }^{26}$ Sermons like these often took on apocalyptic tones, in a negative sense: the own and the known are being endangered, and these forces of endangerment should be resisted at all costs - because, if the own and the known are destroyed, the world has come to an end. The basic experience that these sermonic voices called for, and created, was that of fear. Fear became the fundamental, heuristic experience that provided these sermons with structure and gave them content. ${ }^{27}$

26 Cf. Johan Cilliers, \& Ian Nell, "'Within the enclave" - Profiling South African social and religious developments since 1994", Verbum et Ecclesia, vol. 32, no. 1, 2011, pp. 1-7.

27 In the words of Beyers Naude: "I would like to mention in explaining the Afrikaner's traditional attitude to race is fear... for the ordinary Afrikaner his traditional enemy 
It is into this sermonic world that people like Tutu, Boesak, and Naude stepped. In this paper, I limit myself to some comments on Tutu's homiletical legacy. ${ }^{28}$ The evocative power of many of his sermons was remarkable. $\mathrm{He}$ continuously painted alternatives, using many rhetorical techniques. ${ }^{29}$ He challenged the backwards movement of perverted eschatology, when he for instance, while standing over the coffins at a mass funeral in the darkest and ugliest days of apartheid, shouted to the rulers of South Africa, "Come, before it's too late, join the winning side!" ${ }^{0}$ Or, at the funeral of Steve Biko - seemingly the death blow to the liberation movement - where Tutu boldly declares: ${ }^{31}$

There is no doubt whatsoever that freedom is coming. (Yes, it may be a costly struggle still, but we are experiencing today the birth pangs of a new South Africa.) The darkest hour, they say, is before the dawn. We are experiencing the birth pangs of a new South Africa, a free South Africa, where all of us, Black and White together, will walk tall, where all of us, Black and White together, will hold hands as we stride forth on the Freedom March to usher in the new South Africa where people will matter because they are human beings made in the image of God. We thank and praise God for giving us such a magnificent gift in Steve Biko and for his sake and for the

always had a black face or included one - and it is this fear which determined so much of his attitude and policy towards his non-white neighbour in this country." Beyers Naudé, "The Afrikaner and Race Relations," In Hansen, L.D. (ed.), The Legacy of Beyers Naudé (Stellenbosch: Sun Press, 2005), 59.

28 The legacies of Boesak and Naude are discussed in for instance Hansen, L. (ed.), The legacy of Beyers Naudé: Beyers Naudé Centre Series on Public Theology Volume 1 (Stellenbosch: Sun Press, 2005); Hansen, L. \& Vosloo, R. (eds.), Oom Bey for the future: engaging the witness of Beyers Naudé: Beyers Naudé Centre Series on Public Theology Volume 2 (Stellenbosch: Sun Press,2006); Johan Cilliers, The Living Voice of the Gospel? Re-hearing a Prophetic Voice from Apartheid South Africa. Viva Vox Evangelii - Reforming Preaching. Societas Homiletica 9, Hrsg Jan Hermelink und Alexander Deeg (Leipzig: Evangelische Verlagsansalt, 2013), 161-180.

29 Such as metaphor, irony, parody, lampooning, indirect rhetoric, etc. Cf. Charles Campbell and Johan Cilliers, Preaching Fools. The Gospel as a Rhetoric of Folly (Waco, Texas: Baylor University Press, 2012), 181ff.

30 Quoted in a sermon by Peter Storey, Goodson Chapel, Duke Divinity School, November 2, 2010 .

31 September 1977, in King William's Town. Steve Biko was one of the most influential and gifted black leaders during the time of apartheid; he was murdered while in police custody. Cf. Desmond Tutu, Hope and Suffering: Sermons and Speeches (Skotaville: Johannesburg, 1983), 12-16. 
sake of ourselves, Black and White together, for the sake of our children, Black and White together, let us dedicate ourselves anew to the struggle for the liberation of our beloved land, South Africa. Let us all, Black and White together, not be filled with despondency and despair. Let us Blacks not be filled with hatred and bitterness. For all of us, Black and White together, shall overcome, nay, indeed have already overcome. ${ }^{32}$

In the rhetorical repetition of "Black and White together," shockingly spoken in the midst of apartheid following the horrendous murder of Biko, Tutu engages in rhetoric that transgresses the rigid, hostile boundaries between blacks and whites. Indeed, in concluding that black and white together "have already overcome," Tutu invites his hearers into a new creation, which has already broken into the world. This is politicaleschatological preaching of the novum at its best. Dare I say: this represents a truly African Udaba: an event that evokes experiences, that challenges the status quo of divided communities to change; that opens up hope in an eschatological manner - hope for a new community. These are words, a voice that brought glimmers of light in the darkness of apartheid.

Tutu often made use of humour. Humour could be interpreted theologically as being inherently eschatological. It reminds us that the present reality is not the only or final reality, and that our hope lies within the fulfilment of God's promises and actions. It offers us lenses to focus on the promises of God's future prepared for us. At the same time, however, humour makes us aware of the presence of this future, the in breaking of the new creation in the midst of the old. This awareness prevents us from fleeing toward the future, or becoming stuck in the past. Humour creates distance between reality, and us yet this distance never involves escapism, but rather a new perspective on things. Humour intends and expects change; laughter is for the sake of transformation. Humour lives in the present and looks toward the future with eschatological hope. And, of course, there are few rhetorical structures, or oral events, that evoke such distinct experiences such as humour!

32 Desmond Tutu, Hope and Suffering, 15. 
Humour relativizes and unmasks. In a remarkable speech on black South African perspectives and the Reagan administration, Tutu begins with this sentence:

A drunk, so the story goes, crossed the street to accost a perplexed pedestrian and asked, "I shay, which is the other shide of the street?" Nonplussed the pedestrian replied, "That side of course!" "Shtrange," said the drunk, "when I wash that shide, they shaid it was thish shide." ${ }^{33}$

"When is this side the other side?" Tutu essentially asks. All "sides" become relativized. Tutu's joke may sound rather innocent, but the notion of "sides" was, and to a large extent still is, a painful reality in South African society. One person's freedom fighter was another's terrorist, and vice versa. The whole sad era of apartheid could, as a matter of fact, be attributed to the fixation with "sides." Tutu's relativizing humour loosened up this notion of "sides" in order to create spaces for inter-facing and reciprocal acceptance. No "side" should be seen as the unassailable status quo.

In short, prophetic preachers like Desmond Tutu spoke in ways that relativized, and in doing so, opened up experiences of hope, of anticipation of a novum that in fact was celebrated as already being present. While fear formed the heuristic experience in stereotypical apartheid sermons, causing the listeners to cling to the past, anticipation was the fundamental experience evoked by political and eschatological preachers like Desmond Tutu - opening up hope for the future, already celebrated in the present.

\section{Where have all the prophets gone?}

Homiletician Leonora Tubbs-Tisdale has asked a pertinent question: Where have all the prophets gone ${ }^{34}$ This is indeed an appropriate question within the post-apartheid context. Many observers lament the fact that the church's voice has, to a large extent, become silent. People like Desmond Tutu are no longer actively preaching, and a prophetical vacuum seems to have resulted.

33 Tutu, Hope and Suffering, 111.

34 Leonora Tubbs Tisdale, Prophetic Preaching. A Pastoral Approach (Louisville: Westminster John Knox, 2010), 1-3. 
During the days of apartheid church-going members were told time and again that they had an anchor in analogical biblical histories. ${ }^{35}$ Security lay in the fact that the God of these histories was on their side, against their "enemies". Over many decades, and through thousands of sermons, this myth was shaped and kept intact: if the Afrikaner household acted according to (this specific interpretation of) the biblical histories, all would be well. God would secure their future.

After the demise of apartheid and the shattering of the myth, it is clear that many of these people are desperately looking for security, historical links and anchors - as an expression of their search for identity. The church, and specifically also the preaching within this church that has indoctrinated them for so long have fundamentally disillusioned them. Many people no longer trust the church, or at least have lost their blind and naïve loyalty to the church. The anchors that kept them tied to their moorings have been cut. Stability has become instability; a defined identity has been replaced with the search for a new identity. The shattering of the old myth has opened up a vacuum - the question now is: what new myths are being embraced by the disillusioned?

The first and foremost problem facing the church is simply that many of these people are no longer present; the audiences who listen to sermons are rapidly decreasing. The past decade has seen a dramatic decline in the membership of the so-called mainline churches in South Africa specifically also the Dutch Reformed Church (DRC) - mostly in favour of the charismatic movements, accompanied by a phenomenal growth in the African Independent Churches (AIC).

From these trends it is clear that some of the institutional (mainline) churches are now fighting for survival. Not only are the institutions of these churches viewed with scepticism, but also the theology, or basic dogma, is

35 In this portion of the paper comments are made predominantly from the perspective of the Dutch Reformed Church. Of course, there are a multitude of churches and denominations in South Africa, each with its own stories and contributions in this regard. It is impossible to do justice to the richness of this tapestry within the limitations of this paper. Cf. Johan Cilliers, Preaching between assimilation and separation: perspectives on church and state in South African society. Preaching: Does it make a Difference? Studia Homiletica 7. Eds. Mogens Lindhart and Henning Thomsen (Frederiksberg: Aros Vorlag, 2010.), 67-76. 
no longer accepted as obvious. The argument is understandable and goes like this: if the church misled us once in such a fundamental way, how are we to know that it will not do the same again? Many simply no longer engage in dialogue with the church.

This syndrome of apathy could also be ascribed to the accelerated dawn of modernity on South Africa since 1994. Whereas the country was isolated up to this point in time, its borders are now open to all the influences of globalization. Processes of secularization and privatization ${ }^{36}$ have been condensed into nineteen years of democracy, with the expectation that South Africans should digest this in a much shorter time span than was the case in many other countries. All of these factors contribute towards the trickling, and in some cases, flooding away of members from the worship services.

One the one hand, preaching has become more tentative than before, no longer emanating from the certainty of a fixed and stable "truth". One the other hand, preachers tend to be very pragmatic in their approach, desperately trying not to rock the (sinking) boat too much. Preaching has to an extent taken on the mode of maintenance, rather than being an expression of innovative theology.

Paradoxically enough, another strand could be identified in the various efforts that are made to retain those members who still show up for worship services, with liturgical experimentation taking place within the DRC in a way that few would dared have dream of before. In many cases congregations are structured according to market-driven and consumerist considerations, coupled with the copious use of modern technology. Preaching and liturgy have become geared towards the attraction and entertainment of people.

A common denominator in most of these homiletic and liturgical practices seems to be the fact that they are fundamentally introversive. Whilst many (mostly white) South Africans have immigrated to other countries, those remaining in South Africa seem to be emigrating inwardly. ${ }^{37}$ The

36 Cf. Hennie Pieterse, "Liturgy on the edge of community." Society for Practical Theology in South Africa, Vol 1, (2008) 1-8.

37 Cf. Jaap Durand, Ontluisterde Wêreld. Die Afrikaner en sy kerk in 'n veranderende SuidAfrika. (Wellington: Lux Verbi.BM, 2002) 60. 
hermeneutical movement of the apartheid era into the potential of the people's pietistic reserves now takes on different forms: no longer to rectify the state of society according to certain nationalistic ideals, but simply to escape from all responsibilities regarding the new South African society. This stance is sometimes embodied in what could be called an ascetic liturgy, in which, for instance issues such as poverty are not reflected at all. ${ }^{38}$ Ethical preaching that impacts on societal issues seems to be glaringly absent. $^{39}$

It is clear that South Africa, as a young democracy, is struggling to find its identity. ${ }^{40}$ In the euphoria of the political transition in 1994, much was made of the uniqueness of South Africa as a "unity in diversity", epitomized in Archbishop Desmond Tutu's colourful phrase: rainbow nation. The dark days of ethnocracy and pigmentocracy seemed to be over. Since then, however, there have been some indications that people are again retreating into ethnic categories when trying to define their identity, sometimes even in fundamentalist ways.

38 Cf. Johan Cilliers, Cas Wepener, "In herinnering aan die kinders ... wat aan honger en koue moet sterf. Liturgie in 'n konteks van armoede." Dutch Reformed Theological Journal/NGTT Volume 45/2 (2004) 364-372. Also Johan Cilliers, Cas Wepener "Ritual and the Generation of Social Capital in Contexts of Poverty: A South African Exploration.” International Journal of Practical Theology Volume II, Issue 1 (2007) 3755.

39 This is not new, at least within certain sectors of the South African context. Research done on trends in Afrikaans religious programmes as far back as 1987 indicates that the religion that was offered to ordinary Afrikaans-speaking people then was almost always imperative in nature, but not as an appeal that affects the daily and concrete reality. It rather was a type of alien-to-daily-life, non-existential appeal on the grounds of pietistic potential. The programmes' contents said virtually nothing about the issues that, for instance, received attention in the daily press. This research, conducted in conjunction with the Department of Journalism at the University of Stellenbosch, found that not one of the ten most commented on issues of the day was reflected in the sermons that were broadcast. Cf. BA Müller, Tendense in Afrikaanse Godsdiens Programme (Stellenbosch: University of Stellenbosch, 1987), 44-46. Allan Boesak, another well-known South African preacher articulates his aversion of pietistic traditions and preaching in the church in no unclear terms, stating that "this kind of theology is often the handmaid of authoritarian structures that preserve the status quo within the church, with the result that the church is being held back to an era that has irrevocable passed." For Boesak, the gospel - and preaching - is about this world, not an "other-worldly theology". Boesak, The Finger of God, 4-5.

40 Cf. Johan Cilliers, "Religious and cultural transformations and the challenges for the churches - A South African Perspective." Praktiese Teologie in Suid-Afrika. Volume 2 (2007) 1-19. 
That this has affected the church and her preaching seems to be evident. A sad expression of this is the fact that the church (at least the Reformed Family of Churches) is still to a large extent separated structurally. Therefore the unified, prophetic voice of (Reformed) churches in South Africa is absent: it is as if the church has lost its energy to protest against societal evils like poverty, corruption, crime, stigmatization, etc.

It is as if the myth of separation between "us" and "them", so integral to the ideology of apartheid, has come back to haunt us.

While fear formed the heuristic experience in stereotypical apartheid sermons, causing the listeners to cling to the past, and while anticipation was the fundamental experience evoked by political and eschatological preachers like Desmond Tutu - opening up hope for the future, already celebrated in the present, it would seem that the current experience evoked by many sermons is that of uncertainty on the one hand (not knowing what the future holds) and introversion on the other (fleeing from political responsibility in the present).

In South Africa we have had our share of preaching events; we have had our variety of preaching experiences. We have, for instance, experienced fear in the past - fear for losing what is known, fear for change. We seem to be experiencing fear again - fear for the future, fear born out of uncertainty. In many ways, we are like Sigmund Freud's child, sitting in the dark, fearing the unknown.

We have heard voices that created worlds of darkness, and we have heard voices that created worlds of light.

It is time for the voices of light to speak up again, so that it becomes brighter. 